This is an Accepted Manuscript of an article published by Taylor \& Francis in Ethnic and Racial Studies on 05/06/16, available online: http://www.tandfonline.com/10.1080/01419870.2016.1109679.

\title{
Learning from Deep Revolutionary Time
}

Vron Ware, Kingston University

Ethnic \& Racial Studies (2015)

Three striking reproductions encapsulate the complexity of David Roediger's extraordinary book. The first, a painting by Thomas Waterman Wood from 1865 , depicts a black war veteran on crutches, an image that was used to support the demand for African American voting rights after the Civil War. The second is a painting by Winslow Homer entitled "Near Andersonville" (101). The representation of an African American women standing in her doorway, the scene of ferocious battle reduced to a smudged section in the top corner, can be read as "the finest portrait of the drama of emancipation"(99). The third illustration, also by Homer, is a wood engraving called "The Empty Sleeve". It shows a white war veteran, one sleeve of his coat pinned to his jacket, riding in a carriage driven by his able-bodied white female consort. As Roediger explains, this particular image, and the short fiction that accompanied it in the original publication, is particularly potent in summoning up the work that needs to be done to calculate the deadly "equations of white manhood and fitness for citizenship" (73) that continue to haunt the United States today.

Like all Roediger's radical explorations of whiteness, Seizing Freedom provides an exemplary case study of how to employ innovative methodological approaches 
to the broad question of 'how history moves' (12). More specifically, in asking how black people changed the course of American history, not just by "making freedom” but also by "making meaning of freedom" (18) Roediger also demonstrates the value of work that is not just intersectional but also comparative. In reading this book with its clear focus on a bloody civil war in one particular country, we see the urgency of thinking more scrupulously in planetary terms today.

The first theme I want to draw out relates to the concept of Jubilee heralded by the self-emancipation of slaves during the Civil War: a period that Roediger describes as "a cyclical time of liberation, of abolition, and of mechanisms of redress that specifically included land distribution" (18). He makes it clear that his book is pitched to contemporary readers who might recognise the notion of revolutionary time through observing, or even taking part in, momentous events as disparate as the mobilisations to oust former President Mubarak in Tahrir Square in early 2011, or perhaps more fleetingly, the Occupy movements that erupted around the same period. By evoking the self-emancipation of slaves as an example of what can happen when the world is turned upside down, Seizing Freedom made me recall reading eye-witness records of revolutionary time that had been seared into my consciousness. Revisiting these literary accounts reminded me not just of what is lost when the period of turmoil is over, but also of the glorious possibilities entailed in breaking through all social and political constraints in the cause of freedom. Who can say they have lived in revolutionary time? How do we know when it happens? 


\section{Magnificent drama}

Perhaps one of the most well-known examples is George Orwell's documentation of the revolutionary spirit that he experienced in the Spanish Civil War, described in Homage to Catalonia (1952).

I had dropped more or less by chance into the only community of any size in Western Europe where political consciousness and disbelief in capitalism were more normal than their opposites. Up here in Aragon one was among tens of thousands of people, mainly though not entirely of working class origin, all living at the same level and mingling on terms of equality. In theory it was perfect equality, and even in practice it was not far from it... (103-4).

However, on his return to Barcelona after a period of fighting with the militias, Orwell discovered the palpable waning of enthusiasm for any kind of revolution.

Of course such a state of affairs could not last. It was simply a temporary and local phase in an enormous game that is being played over the whole surface of the earth. But it lasted long enough to have its effect upon anyone who experienced it. However much one cursed at the time, one realized afterwards that one had been in contact with something strange and valuable (104).

There he compared the changed "social atmosphere" to his earlier experience of revolutionary time in the city. 
When I first reached Barcelona I had thought it a town where class distinctions and great differences of wealth hardly existed. Certainly that was what it looked like. 'Smart' clothes were an abnormality, nobody cringed or took tips, waiters and flower women and bootblacks looked you in the eye and called you 'comrade’ (113).

Looking back, Orwell reflects on the fact that this was "mainly a mixture of hope and camouflage" (113). For a while the working class "believed in a revolution that had been begun but never consolidated" while the bourgeoisie were "temporarily disguising themselves as workers" out of fear (113).

I was also drawn back to an altogether different account of "revolutionary time" that portrayed an act of rebellion performed by adolescent girls. Roya Hakakian is a US-based Jewish Iranian writer whose memoir about her experience of the tumultuous ferment of late 1970s Teheran is subtitled, "a girlhood caught in revolutionary Iran” (2004). As with the war against fascism in Spain, we approach this history already knowing "what happened" and how this event, the Islamic Revolution, also affected the course of world history. Hakakian's account summons up a set of passions, hopes and desires unleashed by the collective movement to end the tyranny of the shah's regime. It also conveys the contagious delirium that follows the suspension of normality. 
What did I understand of the revolution? Nothing I could put in to words. But I recognised it when I saw it. It was in the air. And I breathed it. It was in every new sound, and every sound that had died (2004:121).

Hakakian describes how the atmosphere of a world turned upside down allowed her to transcend deep conflicts within her own family, which was gradually being torn apart by a conflicting desire to flee to America or stay in the hope that the Jewish community, with its deep roots in Iranian history, would be accepted as allies in the post-revolutionary republic.

'To the revolution I belonged. To the rage that unlike me had broken free. It would guide me as no one else could, raise me as no one else knew how. And to be its daughter, I would emulate it in any way I could" (124).

In one particular episode, Hakakian and her fellow students (all female) in their Jewish school were dismayed by their new teacher's announcement that their holidays are going to be curtailed. This woman, "wrapped in a black veil, pulled tightly from every corner, with only a small opening for her bright blue eyes" (152) had been getting on their nerves since she had suddenly replaced their beloved Mrs Ebrahimi. On hearing that they would be deprived of their holiday, the girls decided to teach this authoritarian figure a lesson.

In a stampede, we chanted, "Down with Moghadam" and took to the schoolyard. No one led anyone. No one followed anyone. For most of 1978, kept 
home from school, we had studied the rebels on the streets. We knew the look and sound of a revolution. And we were, at last, making our own.

Several students climbed the plane trees alongside the yard, broke a few branches, and passed them to the rest of us. From her office, Mrs Moghadam and her assistant stood by the window and watched. Yet no one hid. Frenzy had overtaken us. But so had an order that ruled our throng in unison. We marched from the yard into the corridor, now vibrating only to our echoes. We stormed every classroom, inscribed our slogans on the blackboard, looted what we could, and gathered ammunition - balls, brooms, markers, game rackets, and trash pails...The windows crashed one after another. Never had the sound of shattering glass mended so many broken spirits. Never had mayhem brought more peace. All our lives we had been taught the promise of behaving and now we were discovering the importance of misbehaving. Too much fear had tainted our days... This was 1979, the year that showed us we could make our own destinies...Together as girls we had found the courage we had been told was not in us (169).

This reconstructed scene of Jewish girls, barely in their teens, claiming their share of the revolution is all the more dramatic because it hails the brief period when this historic minority were acknowledged as bona fide citizens in the new republic. 
For one spring afternoon, we, the children of Moses, freer of slaves, claimed our share of Iran's revolution...For one afternoon, we, too, became the true daughters of the revolution... We, too, denounced tyranny, tasted the sweetness of liberty. Of victory! (169)

The incident took place after a delegation of senior Jews from Tehran had travelled to meet the imam in the holy city of Qom to clarify their situation. According to Hakakian's rendering of the meeting, they were told: "Moses would have nothing to do with these Pharaohlike Zionists who run Israel. And our Jews, the descendants of Moses, have nothing to do with them, either. We recognise our Jews as separate from these godless Zionists”(137).

The final scene of the book, which took place in 1984, portrays her parents burning all her books, poems and other writings in a desperate attempt to destroy any evidence that might endanger her life and theirs. Soon after this harrowing incident Hakakian and her mother joined the rest of the family in the US, their father following a few years later.

\section{Deep tragedy}

This reminder that revolutionary time not only does not endure, but is followed by periods of savage repression and counter-revolution returns us to a second aspect of Seizing Freedom that I found so compelling: Roediger's dissection of the "deep tragedy" that followed the "magnificent drama" of emancipation (16). Before he recounts how the "closing of the window of revolutionary time made 
for urgent times and sharp debates" (150), he first expands our understanding of the connections between abolitionism and the early women's rights movement by including other "radiating impulses towards freedom" (11) that were set in motion by the revolutionary actions of the oppressed.

In an influential book called Women's Legacy, published in 1982, feminist historian Bettina Aptheker wrote:

The intersection of abolitionism and women's rights in organization and personnel confirmed the revolutionary impulse of the antislavery cause. A mutually compelling dialectical arrangement sustained the two movements, so that each reinforced the radicalism of the other. The female presence helped to shape the revolutionary character of abolitionism and practical engagement in the struggle against slavery impelled a consciousness of a distinctly feminist vision. (Aptheker 1982:13)

At the time in which Aptheker was writing, the histories of both movements were more likely to be written in parallel and these interconnections downplayed. At best it was acknowledged that black and white women performed strategically important but ultimately subordinate roles in the abolitionist campaigns. The breakaway groups organising for women's rights were seen as a direct outcome of the constraints that many white women experienced when speaking in mixed audiences or arguing with male colleagues. 
Yet as she suggests here, the interests and motives of early women's rights campaigners did not so much interconnect with those of abolitionists, but helped to shape the terms in which the abolitionist cause was articulated. The mutually constitutive aspects of both movements went so much further than the practicalities of coalitions or alliances, as Roediger explains so insightfully: "The pro-suffrage campaigns for women and for African-American men shared a sense that the slave's emancipation demonstrated that the nation had entered a period of 'revolutionary time"' (139).

Today we are accustomed to the word "intersectionality" to signify the entanglement of race, class and gender in feminist politics. Seeing it in connection with foundational movements for freedom in the nineteenth century is a reminder that the concept did not, as is commonly assumed, originate in the set of juridical arguments laid out so convincingly by Kimberlé Crenshaw in 1989 . It is a term that, as Crenshaw herself has explained, has long evoked the inseparability of race, class and gender, rooted not just in the material conditions of political struggle for "human freedoms" but also in the bodies and subjectivities of black women. By braiding “the women's movement and the labor movement into the story of Reconstruction and as fully beholden to the selfemancipation of slaves" (15), Roediger follows an intersectional line of argument that both enriches and develops Du Bois' analysis in Black Reconstruction. In his introduction he writes, "In the inspired presence of the self-emancipation of slaves, hundreds of thousands of women and white workers began to think very differently about their own possibilities and desires" (5). This poses further 
questions such as: what do we gain by analysing class-based politics - or specifically those struggles emerging from the conditions of waged work - as an inseparable element of feminist, anti-racist movements? How do we account for the bitter recriminations and fractures that come after the heady days of solidarity and collaboration?

Even before the year 1864 had ended, Roediger notes, there were signs that paths were diverging. Activists were faced with the reality that "The case for AfricanAmerican male suffrage had to be snatched from the last moments of revolutionary time was compelling, but so was the idea that, if missed now, women's suffrage would be a long time in coming" (139). As he analyses the collapse of the American Equal Rights Association (AERA) in the face of "the terrible logic of the mutual recrimination of the feminist and abolitionist movement," he demonstrates that Jubilee was "not without its forces of resilience but neither was it insulated from racism, [and] sexism" (157). Rather than condemning leading individuals from the women's suffrage organisations who resorted to white supremacist and anti-immigration arguments to advance their case for political representation, Roediger situates them within a network of friendships and high profile alliances within which many people made "destructive decisions" (148). By showing that dissent did not fall simply along manichaean fault-lines of black and white, male and female, and that arguments for suffrage were increasingly enmeshed with campaigns over working conditions, he demonstrates "the power of white supremacist ideas to recreate themselves in changed circumstances" (153). 


\section{The empty sleeve}

A third aspect of Seizing Freedom that I found so thought-provoking was Roediger's focus on disability as an analytical lens, particularly in relation to the racialised body of the war veteran. By placing disability at the centre, largely through the important work of theorists such as Douglas Baynton, he draws attention to the fact that "not only are disabled people significant actors in history, but the concept of disability has functioned rhetorically to structure thought about social hierarchies in general" (Baynton 2005:562). Racial science informed the ideology that white men were supremely capable of ordering civilisation, while white women and black people were deemed unfit through their very natures. African men were widely believed to suffer from inherent mental and physical impairments that rendered them incapable of enjoying the benefits of equality with white men. Women were thought to suffer from "physical, intellectual, and psychological flaws" (Baynton 2005: 563) that prohibited them from taking part in the public sphere. While the evidence of the abolitionist and women's rights movements obviously negated these constructs of inherited and innate disability, the deeply-rooted assumptions that underpinned them continued to shape white supremacist ideology, whether in the context of Reconstruction or violent repression elsewhere in the colonised world.

By inserting the figure of the injured male war veteran, whether black or white, Roediger points to the significance of military work within the discourse of white supremacy and citizenship. War and violent conflict can open up less familiar 
angles of analysis that both complement and complicate a conventionally intersectional approach: "Ubiquitous encounters with unthinkable suffering demonstrated how fragile and how ordinary white ability was...Combat put black capability on display" (82). But this is not simply an argument about how ability and disability are marked in and on the male body of the warrior, and how this might qualify the deep structures of racial hierarchy that determined eligibility for citizenship. The effects of war fighting left countless men dependant on women for their physical and material care. In addition to supporting male relatives who were incapacitated, women were increasingly involved as nurses near the scenes of battle, "perhaps the most dramatic example of how disability mattered in reshaping other axes of inequality" (82).

Introducing the book, Roediger states that the application of these themes to Civil War history is also an argument against practising a narrow methodological nationalism. He cites the British practice of raising soldiers from among the slave population in the War of Independence as a key element of this story (7), but I would take this further to suggest that we need a much longer and more detailed analysis of the links between the work of soldiering, the radicalised body and the gendered politics of emancipation from white supremacist rule. For this project the canvas must be stretched across the Atlantic to include Africa, at the very least. When, where and under what circumstances Africans and other enslaved or colonised peoples have been enticed, persuaded or forced to perform military labour on behalf of American or European geopolitical and commercial interests? On what grounds have these former soldiers fought to claim rewards for this 
work, if any, and what were (and are still) the conditions of acquiring compensation for fatal injury or loss of livelihood?

This brief commentary cannot do justice to these inquiries, but two examples will hopefully map out the terrain on which we might glimpse the work to be done. Sixty years before the Civil War, Africans had been employed in British and French armies to fight in the Caribbean. In his detailed history of the West India Regiments raised by the British Army from 1795 to 1927, Brian Dyde explains the rationale for preferring black men over white. Disease, diet and general debilitation in the unfamiliar climate made Europeans poor soldiers, while those of African origin (and particularly those disillusioned by France's negation of revolutionary ideals) not only fared better in the tropical environment but were often motivated politically as well. Long before the doctrine of martial races first provided pseudo-scientific rationalisation of the aptitude of certain ethnicities for warfare, military recruiters in the late $18^{\text {th }}$ and early $19^{\text {th }}$ centuries were ready to prioritise the need for strong male bodies and what would now be called "trainability" in their quest to keep ranks full. This history forms what I have called the "crimson thread" that connects the British enlistment of African "slaves in red coats" to the army's contemporary practices of recruiting directly from Commonwealth countries to counter a shortage of volunteers at home (Ware 2012: 282).

As Dyde documents in his book, The Empty Sleeve, the contingencies of maintaining an army overseas were often at odds with what happened when that 
particular war was over. The abolition of the slave trade in 1807 was no barrier to British recruiters raiding slave ships intercepted in the Atlantic after this date, yet there were no guarantees that the men would be free at the end of their military service. This frames the second set of questions about the rewards and compensations for military work. Staying with the British Army, we see this deadly mix of "whiteness, ability, [and] carnage" (Roediger 2014: 69) in the course of protracted struggles for decolonization and national independence in the twentieth century.

In an essay called "No Country Fit for Heroes", Timothy Parsons examines colonial policies towards disbanded askaris in Kenya before and after the Second World War. "Viewing African soldiers as cheap and expendable," he writes, "colonial governments believed their only obligation to disabled 'native' exservicemen was to provide the basic means to function as patriarchal household heads in subsistence rural societies" (Parsons 2015: 130). Not only were injured veterans expected to rely on their "tribal" communities for material support, those who sought financial compensation or who demanded the more advanced mechanical legs issued to white men, were routinely treated as subversives. I suggest that these details, fragmentary as they are, must be factored into the historic "equations of white manhood and fitness for citizenship" analysed so eloquently in the pages of Seizing Freedom.

Having begun with a set of compelling visual images that evoke the complexity of Roediger's argument, it seems fitting to end with poetry. The title of Dyde's book, 
The Empty Sleeve, is derived from the second of Derek Walcott's 'Two poems on the Passing of an Empire' (Walcott 1964, 21). In the first, he evokes a searing image of a heron flying across the marshes in a landscape recently emptied of Roman military power. In the second, it is the tide of British imperialism that has receded, leaving an old man, one-eyed and with hunched back, to contemplate the residues of colonial rule. The old 'pensioner', a veteran 'of the African campaign', hears the sound of children singing 'Rule Britannia' from his 'coffin' of a house. He is fully aware that in their naïve belief in the heroism of war, future generations of boys would continue to become soldiers and shed their blood for an empty promise, 'for a sieve'. The poem ends with a question: would these young men still believe in 'such a poor flag as an empty sleeve' if they were able to see the profound damage wrought in the bodies of those who went before them?

\section{References:}

Aptheker, Bettina (1982) Woman's Legacy: essays on race, sex and class in American history. Amherst: University of Massachusetts Press. Baynton, Douglas (2005) "Slaves, Immigrants and Suffragists: the uses of disability in citizenship debates", Modern Language Association, PMLA, Vol. 120, No. 2 (Mar.), pp. 562-567. Dyde, Brian (1997) The Empty Sleeve. The story of the West India Regiments of the British Army. St John's, Antigua: Hansib Caribbean. Hakakian, Roya (2004) Journey from the Land of No: a girlhood caught in revolutionary Iran. New York: Crown. 
Orwell, George (1980/1952) Homage to Catalonia. London: Harcourt Brace \& Co.

Parsons, Timothy (2015) "No Country Fit for Heroes: the plight of disabled Kenyan veterans", in Byfield, J.A., Brown, C.A., Parsons, T. and Sikainga, A.A. (eds) Africa and World War I. New York: Cambridge University Press, pp. 127143.

Walcott, Derek. 1964. Selected Poems. New York: Farrar, Strauss \& Co.

Ware, Vron (2012) Military Migrants: fighting for YOUR country. London: Palgrave Macmillan.

Vron Ware has been in conversation with David Roediger since the early 1990 s when Beyond the Pale: white women, racism and history (Verso, 1992) appeared shortly after his book, The Wages of Whiteness (Verso 1991). She has subsequently published Out of Whiteness: color, politics \& culture (2002, Chicago) with Les Back; Who Cares about Britishness? (Arcadia 2007) and Military Migrants: fighting for YOUR country (Palgrave 2012). She is currently professor of sociology and gender studies at Kingston University. 